\title{
ARCHIVO
}

\section{Un testimonio temprano de la lira popular chilena: "Dos poetas de poncho" de Zorobabel Rodríguez}

\author{
An Early Document on Chile's Lira Popular: \\ "Dos poetas de poncho", by Zorobabel Rodríguez
}

Tomás Cornejo C.

Escuela de Historia, Facultad de Ciencias Sociales e Historia. Universidad Diego Portales. Santiago de Chile

\section{RESUMEN}

En 1873 el periodista, académico y escritor chileno Zorobabel Rodríguez publicó un artículo acerca de una manifestación cultural llamativa y novedosa en el país: los pliegos sueltos de poesía. Su texto aporta cuantiosa información sobre la distribución de estos, los temas más comunes de las poesías, su público preferente y el proceso creativo de los poetas, particularmente el célebre Bernardino Guajardo. Además, la posición adoptada por Rodríguez resalta la distancia entre el mundo letrado decimonónico y las formas culturales de los sectores populares urbanos.

Palabras clave: Lira Popular, Literatura de Cordel, Zorobabel Rodríguez, Bernardino Guajardo, Poetas populares, Siglo XIX.

\section{SUMMARY}

In 1873 the journalist, academic and Chilean writer Zorobabel Rodríguez published an article about a striking and novel cultural event in the country: the broadside poetry. His text provides substantial information on the distribution of these, the most common themes of the poems, their preferred public and the creative process of the poets, particularly the famous Bernardino Guajardo. In addition, the position taken by Rodriguez highlights the distance between the nineteenth-century men of letters and the culture of the urban poor.

Key words: Lira Popular, Broadside, Zorobabel Rodríguez, Bernardino Guajardo, Century Popular Poets, 19th.

La literatura de cordel hecha en Chile se conoce genéricamente con el nombre de Lira Popular. Tal designación agrupa a un conjunto de pliegos sueltos de poesía (la mayoría en décimas), creada por medio centenar de puetas entre las décadas de 1860 
y 1920. Su riqueza ha despertado el interés de numerosos investigadores, que tratan de explicar la fuerza expresiva de los versos, tanto como de las imágenes de los pliegos, al igual que la constitución de ese acervo en prueba de la vitalidad de las clases populares chilenas en el tránsito del siglo XIX al XX.

En esta ocasión se presenta transcrito íntegramente uno de los pocos testimonios contemporáneos sobre el particular, "Dos poetas de poncho: Bernardino Guajardo y Juan Morales" (1873), escrito por Zorobabel Rodríguez. El texto presenta interés principalmente por dos motivos. Proporciona un conjunto de informaciones sobre la poesía popular impresa de la segunda mitad del siglo XIX en tanto fenómeno social y cultural. Corresponde a observaciones efectuadas por el mismo autor en Santiago, dando cuenta de aspectos tan importantes como el proceso de composición de los textos, la venta y circulación de los pliegos en el entramado urbano, además de datos e impresiones sobre uno de los iniciadores de este género poético en el país - y considerado su más alto exponente-, Bernardino Guajardo (c.1810-1886).

El artículo de Rodríguez adquiere valor documental porque refiere aspectos poco conocidos de la poesía popular impresa y sus cultores. Historiar a estos ha sido una tarea que en los últimos años ha dado frutos importantes, bajo la forma de reseñas sobre la biografía y la actividad de algunos puetas (Navarrete 1998; Cornejo 2006; Palma 2008) o la publicación de los manuscritos de un recopilador de fines del siglo XIX sobre varios de ellos (Dannemann 2004). En general, la veta más provechosa de información para los investigadores actuales ha sido Rodolfo Lenz (2003). Éste escribió su riquísimo estudio a mediados de la década de 1890, cuando la literatura de cordel chilena estaba en pleno apogeo, pero dejó algunas cuestiones en penumbra. El texto de Zorobabel Rodríguez permite adentrarse en problemas fundamentales como la venta y distribución de pliegos sueltos a pocos años de iniciada esta modalidad poética en la capital, que se ha fechado hacia 1865.

La descripción de Bernardino Guajardo recorriendo los pasillos del Mercado Central recién inaugurado, codeándose con los venteros y clientes habituales resulta esclarecedora, al igual que los datos respecto al precio de sus pliegos y la cantidad que lograba vender por jornada. Junto con esas luces para aquilatar mejor la práctica de los vates populares, es imprescindible conocer cuáles eran sus competencias culturales. Al respecto, el contacto de Rodríguez con los "poetas de poncho" le permite afirmar que, tanto Guajardo, como Morales, tuvieron un vínculo precario con el mundo impreso, formado de retazos de periódicos, novelas clásicas de gran circulación y libros de divulgación religiosa, en lecturas parciales hechas por sí mismos o por intermedio de terceros; algo que lleva a inferir la existencia de ciertas prácticas lectoras subalternas y de correspondientes comunidades de interpretación. Se descubre en las páginas que escribió que en el proceso creativo de los poetas callejeros tenía asimismo un lugar primordial la transmisión oral y la memoria, cuestión que ha sido documentada para otros países (Botrel 1993).

Observador atento del entorno social en que se desenvolvían los poetas, Rodríguez corrobora la idea de que estos eran voceros de las clases trabajadoras, al consignar "en su crónica rimada los sucesos, ora trájicos, ora venturosos, ya de carácter público, ya de carácter privado, que mas profunda impresión han causado al público". Cierto es que el artículo de Rodríguez se centra en la figura de Bernardino Guajardo (incluyendo algunas consideraciones sobre su carácter y sus preferencias políticas que con- 
tribuyen a su biografía), en detrimento de Juan Morales, colega y, al mismo tiempo, competidor de Guajardo. Sin embargo, el espacio que le dedica saca del olvido a este poeta cuyo rastro se ha perdido en las compilaciones chilenas, salvo referencias muy breves (Dannemann 2004: 102-105). Y, más que el contenido de los versos de Morales, destaca el pasaje en que se describe la elaboración de sus composiciones. Siendo éste ciego, el muchacho que oficiaba como su lazarillo era además su ayudante en la transcripción de los versos, intervención que es posible conjeturar si existió también en el caso de otros puetas invidentes — que no fueron pocos-, como Juan Bautista Peralta.

Por otra parte, el largo artículo escrito por Rodríguez testimonia la distancia entre "alta cultura" y cultura popular en un momento clave del desenvolvimiento social chileno. Su autor y el público destinatario del texto eran parte de una elite ilustrada que intentaba llevar a la práctica un proyecto de construcción nacional y que observaba con suspicacia a los grupos sociales subordinados.

Zorobabel Rodríguez (Quillota, 1839-Valparaíso, 1901) fue un claro exponente de esa elite. Estudió leyes y tuvo una actuación destacada como hombre público (diputado entre 1870 y 1891), pero donde más destacó fue en la academia y en las letras. Se le recuerda como uno de los defensores del liberalismo económico desde las aulas universitarias (Correa 1997: 391-392), aunque el ámbito de actividad más señero de Rodríguez fue a través de la pluma. Al igual que sus contemporáneos en los países latinoamericanos, fue un publicista que amalgamó una vocación propiamente literaria y una labor periodística. Entre 1864 y 1884 fue redactor de El Independiente, diario surgido al alero del Partido Conservador para defender los fueros de la Iglesia católica en las pugnas doctrinarias de mediados del siglo XIX.

Esa fue la tribuna que le granjeó a Zorobabel Rodríguez un reconocimiento como hombre de letras. De acuerdo a uno de sus biógrafos, era "un escritor doctrinario, apasionado e irónico, como periodista [...] pero como literato y en especial en su rol de crítico, era un publicista culto, erudito y de un estilo ameno" (Figueroa 1901: 116).

La Estrella de Chile, donde apareció el texto en cuestión, constituyó parte del escenario cultural exclusivo de la elite. Era un semanario concebido como plataforma de encuentro e intercambio literario, dirigido "a la juventud estudiosa i séria, amiga de la ciencia o del arte" (Prospecto 1867: 1). Su propósito era "contribuir, aunque sea en la mas modesta escala, al cultivo de la intelijencia i al incremento de la ilustracion en el país; fomentar la veneracion por la verdad i el gusto por lo bello" (Prospecto 1867: 1). La Estrella de Chile ocupó asimismo una función de ariete periodístico al defender una cierta estética católica contra la arremetida del pensamiento y la literatura laicos en el país (Rodríguez 1871). De esta forma, la publicación polemizó con los órganos de semejante índole aunque contrarios ideológicamente, emanados de otros cenáculos intelectuales, como La Revista de Santiago (Un nuevo colega 1872).

Los números de La Estrella de Chile describen un arco muy amplio de intereses literarios que comunicaban a editores y colaboradores con su selecto público. Si bien la actualidad de las "bellas letras" y otros tópicos contingentes marcaban la pauta, la preocupación por la cultura local no estuvo ausente de sus páginas. Prueba de ello es la publicación de las estampas costumbristas de José Zapiola sobre la sociedad chilena de los inicios republicanos. La aparición del texto de Zorobabel Rodríguez sobre los "Dos poetas de poncho" engarza en parte con esos temas que acuciaban a 
la intelectualidad de la época. Al incursionar en esas avenidas, Rodríguez realizó una labor casi etnográfica, adelantándose a otros estudiosos que a partir de la década de 1890 intentarían sistematizar sus pesquisas sobre los diversos grupos sociales que componían el paisaje humano chileno y sus prácticas culturales (Dannemann 2010).

Es cierto que, en el caso de Rodríguez, hubo además una voluntad personal por acercarse a la cultura vernácula que se iba transformando con rapidez. En La cueva del Loco Eustaquio, su temprano texto narrativo, hay varios pasajes costumbristas (Uribe Echevarría 1973: 5). La misma voluntad se palpa en una de las obras que le valió a Rodríguez mayor reconocimiento - y agudas críticas-, el Diccionario de chilenismos, publicado tres años después del artículo aquí transcrito y en el cual utilizó, para ejemplificar las voces listadas, varios versos de Bernardino Guajardo. Aunque, a decir verdad, el Diccionario pretendía ser una llamada de atención sobre la incorrecta utilización del castellano por parte de todas las clases sociales en el país, cuestión que según su autor se palpaba en las conversaciones coloquiales y, cada vez con mayor evidencia, en la prensa. Los particularismos del habla nacional suscitaban admiración para ser corregidos, más que por lo creativo de sus giros verbales y su adaptación lexicográfica.

En múltiples ocasiones el texto que publicara La Estrella de Chile deja ver las marcas enunciativas que separaban al autor y su auditorio del mundo social descrito. Para Rodríguez, el vate popular escogía temas para "excitar la curiosidad de sus lectores", donde abundaban "cuadros toscos, pero tomados al natural, de las condiciones i circunstancias de su vida". Si alguien se hubiera aventurado a observar dentro de los conventillos y ranchos que habitaban las clases trabajadoras, según el autor, descubriría la correspondencia entre cuanto narraban Guajardo, Morales y sus émulos, y "la vida doméstica que hace la inmensa mayoría de nuestro pobre pueblo". Las coordenadas socioculturales tan disímiles entre el mundo ilustrado y las clases populares avizoradas por medio de sus poetas se advierten también en el plano lingüístico. La efectividad de las décimas de Guajardo surtiría efecto porque éste hablaba a su auditorio "en su propio idioma", compuesto, según Rodríguez, de una "jerga, mitad quichua i mitad castellano de cocina, que hablan nuestros peones i en general nuestras clases ignorantes". Era, en su opinión, un lenguaje "bárbaro muchas veces, pero por lo general expresivo de nuestro bajo pueblo", poblado de los chilenismos a la caza de los cuales andaba.

La alta demanda de poesías picarescas llevaba a pensar a Rodríguez que entre las clases trabajadoras reinaba la inmoralidad. El propio Guajardo, "hombre de pueblo", era factible que cayera "en las groserías, indecencias e inmoralidades en que incurren los de su clase", aunque, por otra parte — destacó el autor del artículo—, el vate era un firme creyente católico. Dicha fe la conceptuó como un baluarte "que aun los hombres mas ignorantes i rudos de nuestra república conservan en lo más recóndito del alma".

Con todo, el interés de Zorobabel Rodríguez por los poetas populares es genuino y forma parte de una cadena que comienza con Adolfo Valderrama en la década de 1860, para recibir un impulso decisivo de mano de los estudios antropológicos y lingüísticos de fines de la centuria, con Rodolfo Lenz a la cabeza. Es de notar que esa cadena moldeó la visión de los hombres de letras respecto a los vates del pueblo con un fondo común. Para Valderrama, al estudiar las composiciones populares era preciso "acercarse a ese entresuelo de nuestra sociedad que se llama el roto" (1866: 
22). Los versos permitían constatar que «en medio de la horrorosa violacion de los mas sencillos preceptos del lenguaje, se encuentran pensamientos de una verdad que pasma, de una grande originalidad" (Valderrama 1866: 154). Lo más valioso de esta forma poética, de acuerdo a este autor, se daba en el campo. Dos generaciones más tarde, quienes recopilaron y estudiaron la poesía popular impresa en el país emitieron juicios muy parecidos. Tanto Lenz (2003: 26,61) como Julio Vicuña Cifuentes (1926: 53-55) lamentaron la pérdida de la práctica poética campesina y su reemplazo, en el ámbito urbano, por una poesía "vulgar".

Este divorcio entre "alta cultura" y cultura popular no debiera sorprender si se considera que es un proceso que se ha dado en otras latitudes y momentos históricos, cuando un contexto de cambios acelerados en el ámbito social y material va aparejado de transformaciones culturales y políticas. En esas circunstancias, una serie de redefiniciones sobre lo nacional llevan a mirar el pasado en una búsqueda paradójica de lo "auténtico" de una sociedad, al tiempo que se intenta moldear —a veces con dosis de imposición y disciplina- el presente de quienes llevan a la práctica las manifestaciones culturales que integran ese conjunto de autenticidad en el presente (Burke 1996: 35-60, 390-396; Caro Baroja 1969: 18).

La pertenencia de Zorobabel Rodríguez a la intelectualidad chilena decimonónica lo llevó, así, a conocer una manifestación cultural que se multiplicaba por calles y plazas con la velocidad de la imprenta. Se acercó a los pliegos de poesía con ojos escrutadores y, en un gesto típico de su tiempo, recolectando una abundante muestra de ellos para formar una colección nada despreciable (de la cual se desconoce su paradero), según él mismo informa. Tal vez el único descuido en esta tarea fue que en la publicación original del artículo, Bernardino Guajardo es aludido erróneamente como "Gallardo". Esa equivocación ha sido subsanada en la presente transcripción, la que se ofrece, conservando su ortografía original, con la intención de facilitar la consulta de una fuente de difícil acceso, imprescindible para conocer la poesía popular chilena y quienes la creaban.

\section{BIBLIOGRAFÍA CITADA}

Botrel, J. F. 1993. Libros, Prensa y Lectura en la España del siglo XIX. Madrid: Fundación Germán Sánchez Ruipérez.

Burke, P. 1996. La cultura popular en la Europa moderna. Madrid: Alianza.

Caro Baroja, J. 1969. Ensayo sobre la literatura de cordel. Madrid: Ediciones de la Revista de Occidente.

Cornejo, T. 2006. "Juan Bautista Peralta: cantor, poeta, periodista popular", en Navarrete, M. y Cornejo, T. (comps.), Por historia y travesura. La Lira Popular del poeta Juan Bautista Peralta: 2334. Santiago: Archivo de Literatura Oral y Tradiciones Populares, Biblioteca Nacional-Centro de Investigaciones Diego Barros Arana-Fondart.

Correa, S. 1997. "Zorobabel Rodríguez, católico liberal". Estudios Públicos 66: 387-426.

Dannemann, M. 2004. Poetas populares en la sociedad chilena del siglo XIX. Estudio filológico. Santiago: Archivo Central Andrés Bello, Universidad de Chile.

Dannemann, M. 2010. "Tres buscadores de la chilenidad: Lenz, Laval y Vicuña Cifuentes". Anales de Literatura Chilena 14: 57-92.

Figueroa, P. P. 1901. Diccionario biográfico de Chile, tomo III. Santiago: Imprenta, Litografía y Encuadernación Barcelona. 
Lenz, R. 2003 [1895]. Sobre la poesía popular impresa de Santiago de Chile. Contribución al Folklore Chileno. Santiago: Centro Cultural de España - Biblioteca Nacional de Chile.

Navarrete, M. (comp.) 1998. Aunque no soy literaria. Rosa Araneda en la poesía popular del siglo XIX. Santiago: Archivo de Literatura Oral y Tradiciones Populares, Biblioteca Nacional.

Palma, D. 2008. "¡Crucen chueca que aquí hay peón'. Daniel Meneses, el poeta nortino", en Navarrete, M. y Palma, D. (comps.), 'Los diablos son los mortales'. La obra del poeta popular Daniel Meneses: 51-71. Santiago: Archivo de Literatura Oral y Tradiciones Populares, Biblioteca Nacional - Centro de Investigaciones Diego Barros Arana - Fondart.

Prospecto. 1867. La Estrella de Chile 1: 1-2.

Rodríguez, Z. 1871. "Nuestro ideal literario". La Estrella de Chile 211: 17-20.

Rodríguez, Z. 1875. Diccionario de chilenismos. Santiago: Imprenta de El Independiente.

Un nuevo colega i la fraternidad literaria. 1872. La Estrella de Chile 238: 1-3.

Uribe Echevarría, J. 1973. Tipos y cuadros de costumbres en la poesía popular del siglo XIX. Santiago: Pineda Libros.

Valderrama, A. 1866. Bosquejo bistórico de la poesía chilena. Santiago: Imprenta Chilena.

Vicuña Cifuentes, J. 1926 [1916]. "La poesía popular chilena", en He dicho: 17-76. Santiago: Ed. Nascimento. 
Rodríguez, Zorobabel. 1873. "Dos poetas de poncho: Bernardino [Guajardo] i Juan Morales". La Estrella de Chile 304: 763-766; 305: 775-779; 307: 823-826; 308: 839-841; 309: 856-859.

'Dos cosas me han llamado especialmente la atencion, nos decia no ha mucho un ilustre extranjero recien llegado a Santiago, la riqueza e ilustracion de la clase mas elevada de este pais, i la ignorancia i la miseria de las clases mas bajas. Son como dos pueblos superpuestos que recíprocamente se ignoran. A mi humilde i todavía (puesto que acabo de llegar) aventurado juicio, la grande obra señalada por Dios a la actividad de la generación rica e ilustrada que crece es colmar el foso que separa a los dos pueblos que aquí viven en roce contínuo, pero sin conocerse.'

La observacion del viajero aludido nos pareció exacta, i hoi la hemos recordado naturalmente al escribir los dos nombres que van a la cabeza de este artículo. En efecto ¿habrá acaso alguno de nuestros lectores que no se haya preguntado a sí mismo: ¿quiénes son Bernardino Guajardo i Juan Morales? ¿I qué poetas serán estos cuyos nombres no hemos vistos figurar nunca entre los colaboradores de las revistas literarias, cuyas poesías no han sido hasta la fecha dadas a la estampa ni recopiladas en ningun libro? Sin embargo, esos dos nombres, como luego hemos de verlo, son los de dos poetas chilenos i santiaguinos, mui fecundos i extraordinariamente leidos i aplaudidos.

El uno i el otro han encontrado en su público recursos bastantes para costear la impresion de sus versos, i Guajardo, el mas antiguo i popular de entrambos, ha visto agotarse en no mucho tiempo diez ediciones de algunas de sus coplas i puede con razon decir al mas empingorotado de nuestros vates: ¡Soi en Chile el único poeta que vive de sus versos!

I ello se comprende, porque Guajardo es para la inmensa mayoría de la población de Santiago el fabricador i espendedor de un artículo que en la capital de Chile como en todas partes es de primera necesidad. En efecto, tan equivocado andaria quien se imaginase que el vulgo es insensible a las armonías de la rima i que los rudos trabajadores no experimentan la necesidad de retener en la memoria algunas estrofas con que aliviarse de las fatigas del trabajo, como el que sostuviese que, por cuanto los peones no se visten de paño i sus mujeres no se engalanan con encajes i piedras preciosas, aquellos no necesitan de vestidos i éstas no sienten el deseo de parecer hermosas. El hombre, cualquiera que sea el lote que le haya cabido en suerte en este mundo, es siempre el mismo; i si la educacion, las costumbres i el medio en que se vive pueden corromper o purificar los sentimientos, ennoblecer o degradar los caracteres, ilustrar o deprimir las inteligencias, ni la educación, ni las costumbres ni el medio en que se vive son bastante poderosos para extinguir en el alma sus aspiraciones innatas ni sus naturales instintos. De ahí es que, asi como ha podido decirse con fundamento que la idea de Dios es comun a todos los pueblos de la tierra, puede afirmarse con verdad que en todos los pueblos de la tierra se ha dibujado, se ha escul- 
pido, se ha bailado i cantado. Eso dice la historia i eso nos dicen todavía los últimos descubrimientos que ha hecho la paleontolojía humana. El hombre de la edad de piedra, dibujaba ya en las hojas de sus hachas los combates que sostenia con los osos de las cavernas, e imitaba en los mangos de sus puñales de marfil la cabeza de un mammouth o de un reno.

No es de admirar por lo tanto que en todas las épocas i pueblos haya existido una poesía popular; a veces conjuntamente con la culta, si bien distinta de ella, i a veces tambien sola, cuando por cualquier causa la primera ha llegado a extinguirse. La poesía culta, fruto i necesidad de los pueblos o clases que han llegado a cierto grado de civilización, se desenvuelve, decae o perece conjuntamente con ésta. La poesía popular, fruto i necesidad del hombre en todas las condiciones de su existencia, no podria desaparecer de la tierra sino con el hombre mismo. Existe en todas partes, con abundancia portentosa, i si en ocasiones la echamos de ménos i se nos imajina que calla, es porque no hai nadie que se tome el trabajo de observar con cuidado el terreno que pisa i de poner el oido para sorprender sus gratos, aunque humildes i toscos acordes.

Bernardino Guajardo es en la actualidad el mas aplaudido representante de la poesia popular en nuestro pais. Si quereis divisarlo, id cualquier mañana de Dios a la plaza de abastos (pues suponemos que en su calidad de discípulo de Apolo, a pesar de su poncho, tenga todavía franca entrada a ella) i buscadlo atentamente, que lo encontrareis entre las verduleras que venden i las fregonas que compran, ya sentado en nutrida plática con las chocolateras, ya en contínuo movimiento desde los baratillos de afuera a la puerta, i desde la puerta a las callejuelas interiores de aquella animadísima feria. Alto de cuerpo, enjuto de carnes, tuerto de un ojo i del otro no mui bueno, Guajardo debe tener allá como unos cincuenta i cinco años de edad. Como el albañil-enjerto en sastre de Quevedo, que marchaba siempre con su casa a cuestas, Guajardo marcha siempre con la colección de sus obras debajo del brazo.

A diferencia de los demas vendedores ambulantes, nuestro poeta no pregona sus mercaderías; reserva que guarda, talvez por el decoro de las musas, talvez porque estima que la misma popularidad de que goza haria inútiles los pregones i encarecimientos de costumbre. Lo cierto del caso es que Guajardo es invitado a cada instante a detenerse, a desabrochar el cuero mugriento i sobado por el contínuo frote en que lleva forradas sus coplas, i a ofrecer al comprador las que desee, a razon de dos centavos cada una. Se nos asegura que la venta que hace nuestro vate de sus poesías fluctúa entre 60 centavos i un peso diario; modesta suma con que el pobre atiende al propio sustento i al de su familia.

Pero ¿en qué consisten las producciones de este singular romancero? -Materialmente consisten por regla jeneral en una cuarteta de versos de a ocho sílabas, ya asonantados, ya aconsonantados, picarescos o sentenciosos. Vienen en pos cuatro décimas, cada una de las cuales termina ordenadamente por uno de los versos de la cuarteta, i concluye todo por una quinta décima en que el autor se esfuerza por resumir las idea[s] 
de la pieza, i a veces tambien por dar algo que podria llamarse la moral del cuento. Tales son las composiciones que Guajardo hace imprimir en tiras de diversos colores i que espende por sí mismo a dos centavos cada una.

En cuanto al fondo, son de una variedad que resiste a toda tentativa de clasificacion. Las hai a lo divino i a lo humano, es decir relijiosas i profanas, históricas i científicas, políticas i de costumbres, morales, filosóficas, satíricas, etc. Por punto general i como fácilmente lo sospechará el lector, las décimas de Guajardo carecen de correccion, de gracia, de poesía i de verdad, i no pocas hasta de sentido. Sus chistes son las mas de las veces groseros i de vez en cuando indecentes. Sus lecciones de geografía i astronomía hacen reir, i sus sermones no son siempre de la moral mas pura.

Pero a pesar de todo i puesto que las décimas de nuestro burdo poeta tienen demanda en el mercado, es preciso que tengan algun mérito. ¡I vaya que lo tienen para los compradores! Desde luego Guajardo les habla en su propio idioma; en esa jerga, mitad quichua i mitad castellano de cocina, que hablan nuestros peones i en jeneral nuestras clases ignorantes. En seguida el fondo mismo de las piezas — relijion, moral, costumbres, sentimiento- es un fondo que puede tocar la mas vulgar inteligencia, que es perfectamente conocido del público a quien se ofrece por enseñanza o entretenimiento. I por último, si no siempre, mui a menudo Guajardo, guiado por su instinto, elije por temas de sus versos asuntos propios para excitar la curiosidad de sus lectores, ofreciéndoles cuadros toscos, pero tomados al natural, de las condiciones i circunstancias de su vida.

Son, pues, las composiciones que llamaremos de costumbres las que tienen mayor mérito intrínseco, i cosa notable, son esas tambien las que han obtenido mayor voga. Así, por ejemplo, uno de los romances de Guajardo que cuenta mayor número de ediciones (ocho por lo ménos), es el que lleva por título Celos de la Lora al Loro. Tambien es de los mejores de la colección que tenemos en nuestro poder, compuesta de mas de ochenta i tantas piezas. Dice como sigue:

Le dijo la lora al loro:

- Lorito, dame la pata.

El lorito le decia:

- No te la doi, lora ingrata.

—Loro viejo, desplumado,

Por no asistir a tu casa

Verás, pues, lo que te pasa

El dia ménos pensado.

Tú remueles sin cuidado,

I yo con tus hijos lloro

De necesidad, e imploro

Sola el ausilio del cielo.

Mira si es justo mi celo,

Le dijo la lora al loro.

Ya no te acuerdas que tienes

Hijos a quien mantener;

Donde tu pobre mujer
Una vez al año vienes.

¿Hasta cuándo te entretienes

Con esa ramera ñata?

Lo que te vea sin plata

Tratará de despedirte,

I hoi te engaña con decirte:

Lorito, dame la pata.

—Quítate de mi presencia,

Contestó el loro con prosa:

Deja lora fastidiosa,

De fregarme la paciencia.

Ya ve[s] que la subsistencia

Te la doi dia por dia

Aunque en una serranía

Esté, de allá vengo a verte;

Es prueba que sé quererte,

El lorito le decía. 
-Ojalá nunca te viera

En mi casa, loro indino,

Deseo que en el camino

Un cazador te saliera,

I mil pedazos te hiciera,

A vos con esa mulata:

Vete con ella, pirata,

I dame a mí una mesada,

-Por justicia ni por nada,

No te la doi, lora ingrata.

\author{
Al fin se hubo de ausentar \\ El loro, i la lora fué \\ A demandarlo por que \\ Dejase de tunantear. \\ El juez lo mandó llamar \\ I le raspó bien el cacho \\ -Esto te pasa por lacho. \\ Salió diciendo la lora. \\ ¡Yo veré si vas ahora \\ A odiarme, loro borracho!
}

Aun a riesgo de que nuestro aserto vaya a provocar la risa de mas de un lector, declaramos que la anterior composicion es de un notable mérito. Ella es el cuadro profundamente verdadero de la vida doméstica que hace la inmensa mayoría de las familias de nuestro pobre pueblo. Quien se dé el trabajo de penetrar en los cuartos de los conventillos i en los ranchos, encontrará de diez veces nueve en accion la escena que Guajardo nos describe en las décimas que quedan copiadas. -El marido que remuele sin cuidado, sin asistir a su casa, mientras la pobre mujer llora de necesidad con sus hijos; los celos que ésta le da de la ñata de enfrente o del lado, con quien el mal esposo i padre desnaturalizado se entretiene, malgastando el dinero ganado en la semana; la desenfadada i prosuda respuesta del tunante que no tolera le frieguen la paciencia por cosillas tan insignificantes; la disputa sobre la mesada que ella pide i que él niega; la demanda enta el inspector para que el hombre se deje de tunantear, la consiguiente raspada de cacho que echa al calavera el juez representante de la moral pública, i hasta la burla que, al salir a la calle, hace la guapa mujer al perdidoso lacho.

Todo eso lo hemos visto i oido, porque esa es la vida cuotidiana de millares i de centenares de millares de familias. Si pasamos ahora del fondo a la forma, tendremos que reconocer que la naturalidad de ésta es solo comparable con la verdad de aquél. En efecto, las décimas de Los celos de la lora al loro están escritas en ese lenguaje, bárbaro muchas veces, pero por lo jeneral expresivo de nuestro bajo pueblo. Casi no hai un verso que no contenga algun chilenismo de palabra o de frase.

Lo único que falta al romance que analizamos, es la intencion moral. El poeta se limita a desempeñar el papel de narrador. Presenta a nuestra atención la suerte infeliz de una mujer (casi diriamos de la mujer) del pueblo, sobre cuyos hombros el marido ha echado la doble cruz de la infidelidad i el abandono; pero no tiene ni una palabra de consuelo para la víctima, ni una de censura para el tunante.

\section{III}

Esa intencion moral no se echa de ménos, sin embargo, en todos los romances de Guajardo: i mas de uno tenemos a la vista que habrá hecho, sin duda alguna, a la jente ignorante mas bien que el que hayan podido hacerle los mas elocuentes artículos de diario o de periódico.

Nuestros lectores no habrán echado en olvido las alarmas que despertó en la sociedad el movimiento de emigracion hácia el Perú, estimulado por los ajentes de Mr. 
Meiggs, poco despues de haber contratado este caballero el ferrocarril de Mollendo a Arequipa. Frescos han de estar tambien en su memoria los esfuerzos hechos por la autoridad civil i eclesiástica, i por todos los órganos de la prensa para poner atajo a la fatal corriente, ilustrando a los emigrantes sobre la suerte que les aguardaba en el término de sus aventuras.

Pues bien, en aquella emergencia Bernardino Guajardo se unió a las autoridades i a los diaristas para retraer a sus hermanos de la idea de abandonar el suelo de la patria; i no es aventurado suponer que muchos prestasen oido a las patrióticas advertencias que les dirijió en dos romances, titulado el uno Los enganchados, i el otro Los pobres chilenos en el Perú. El primero nos inicia en el procedimiento, bien poco humano por cierto, que los ajentes del señor Meiggs empleaban para reclutar a los emigrantes, i es una confirmación esplícita de los rumores que entonces circularon i a los cuales no quisimos dar crédito. Véanse sus primeras estrofas:

¡Voi al enganche $i$ me engancho!

Iba un pililo diciendo;

En siete pesos me vendo,

No he de valer mas que un chancho.

Éste era un ocioso vago,

Que a nadie le trabajaba:

Paseándose se llevaba

Por las calles de Santiago.

A fin de hacer un estrago

Queria incendiar un rancho:

Se curó, e hizo pecho ancho,

I sobre picado dijo:

'Ahora mismo de fijo

Voi al enganche i me engancho.'

Se enganchó i todo talló,

No dejó una sola chaucha:

Le aguaitó un pillo con laucha
I la banca le copó.

Al depósito pasó

Donde se llevó durmiendo:

Despertó como sintiendo

Que le estaban dando huasca.

¡Maldita sea la rasca!

Iba un pililo diciendo.

Despues otro compañero

Fue a tallar con valentía,

A ver si ganar podía

I rescatar al primero.

Perdió tambien su dinero

I se quedó maldiciendo;

Un rengo llegó pidiendo

La plata con mucho arrojo

I dijo: yo, por ser cojo,

En siete pesos me vendo.

El segundo es una pintura de los trabajos i miserias que aguardaban en el extranjero a los enganchados, pintura hecha con el bien trasparente propósito de disuadir a los peones de la idea de abandonar su tierra natal. Calcule el lector, recorriendo por sí mismo las décimas de este romance, el efecto que debieron causar en los pililos a quienes iban dirijidas:

Los chilenos enganchados

Que se lleva el extranjero

Con el rigor mas severo

Van a ser sacrificados.

Aquí los enganchadores

Les ofrecen buen salario,

I allá todo es al contrario

Para los trabajadores.

Sufren las plagas mayores
Aquellos desventurados, Muchos de esos desgraciados

A su pais no volverán;

I mui gustosos se van

Los chilenos enganchados.

$\mathrm{El}$ interes de adquirir

Con su trabajo fortuna,

Los lleva sin duda alguna

A padecer i morir. 
Allí sin poder salir

Trabajan un año entero:

Hablando lo verdadero,

Para Chile son atrasos

La falta de tantos brazos

Que se lleva el extranjero.

Para Costa-Rica jente

Mister Meiggs va a llevar.

De lo que van a pasar

Algo les haré presente:

El cólera comúnmente

No cesa de enero a enero,

Otros por el injeniero

Mueren en una prisión

En dura persecucion

Con el rigor mas severo.

Vómito negro i terciana

Esa es otra pestilencia,
Que acaba con la existencia

De toda criatura humana;

En la travesía insana

Algunos quedan botados,

Sin alientos, extenuados,

Moribundos nada ménos.

De este modo los chilenos

Van a ser sacrificados.

¡Ea! chileno engañado,

Si quieres ir al Perú

Mira bien la esclavitú

A que vas esclavizado;

Por lo que otros han pasado

Podía escribirse un libro.

Dí, si como ellos emigro,

Muero en estado fatal

I aquí en mi patria natal

No hai semejante peligro.

No se crea, sin embargo, que para dar tan prudentes i bien intencionados consejos a su público, Guajardo haya necesitado del estímulo de hechos como la emigración a las faenas de los ferrocarriles peruanos; que son muchos los romances suyos de un carácter exclusivamente moral, compuestos para poner de relieve las ventajas de la virtud i la fealdad i funestas consecuencias de los vicios mas dominantes entre los pobres. Así, el que comienza:

'Atiendan, señores maestros, Los que tuvieren oficio, Por que a robar no mas tiran I del alma no hacen juicio,'

es una invectiva en forma contra las trapazas, enredos i mentiras de los artesanos. Carpinteros, sastres, zapateros, herreros, albañiles, talabarteros, tapiceros, mercachifles, 'que conocen desde léjos a los inocentes', dependientes, 'que pueden al mismo diablo sacarle muelas i dientes', los que en licores jiran i 'mas en agua que en licor, todas jentes sin pudor, porque a robar no mas tiran', el cigarrero engordado i vestido de capa por su lucrativa industria 'que con vástago de papa hace cundir el tabaco', i hasta los receptores $i$ abogados que pasan mui bien la vida 'haciendo a otros desgraciados i quitándoles lo propio', todos, según Guajardo,

'De Satanás al servicio

Faltan a su obligación

I bailando al mismo son

De sus almas no hacen juicio'.

Otras veces nuestro romancero, abandonando la sátira, procura alejar a sus lectores de los vicios, poniéndoles ante los ojos las miserias de sus víctimas. ¿Se trata, por ejemplo, del juego? Guajardo empieza con esta cuarteta: 
'No hai pluma con que escribir

La vida del jugador, El mas agudo escritor

No lo sabrá referir'.

Despues, en las cuatro décimas destinadas a desarrollar el pensamiento que aquella contiene, refiere la inquietud contínua en que el jugador vive, lo que hace sufrir a su familia, el riesgo inminente que corre de quedarse en la calle i hasta el mucho mas sério, si bien mas lejano, de ir a la penitenciaria o de ser fusilado; i termina en la quinta décima exhortando a sus oyentes a apartarse de tan funesto vicio en la siguiente manera:
'Al fin hago ver, señores,
Las pésimas consecuencias
I las torpes ocurrencias
Que hai entre los jugadores.
Temé el juego i sus ardores
En vista de este ejemplar:
Toda tertulia de azar
A mas la prohibe el código
Porque como el hijo pródigo
Algunos suelen quedar'.

Son numerosísimos los romances de Guajardo, que podríamos llamar de costumbres, morales i satíricos. En la imposibilidad de copiarlos i en el deseo de ir presentando muestras de todos los jéneros, nos bastará para dejar el que estamos considerando, trascribir las cuartetas que sirven de tema a algunos de aquellos a que aun no hemos hecho referencia. Entre los de costumbres el que empieza,

$$
\begin{aligned}
& \text { 'Es confusión verse un pobre } \\
& \text { Sin plata ni que vender, } \\
& \text { Tener la madre a la muerte } \\
& \text { I de parto a su mujer', }
\end{aligned}
$$

es una pintura intencionalmente exajerada de las angustias i apuros en que vive el pobre. Tambien en éste como en el anterior el poeta termina dirijiendo una exhortación a los lectores, para que busquen en el amparo de la Providencia remedio contra los golpes de la fortuna, como a continuacion va copiado:

$$
\begin{aligned}
& \text { 'Señores, sin duda alguna } \\
& \text { El que mas poder ejerce } \\
& \text { Aun no está libre de verse } \\
& \text { Burlado de la fortuna. } \\
& \text { En esta vida importuna } \\
& \text { Todo es sombra o apariencia: } \\
& \text { Imploremos la clemencia } \\
& \text { Del Dios de suma bondad, } \\
& \text { Que nos mire con piedad } \\
& \text { Por su augusta Providencia'. }
\end{aligned}
$$

El titulado El rodante, que a diferencia de los demas, consta solo de cinco décimas, careciendo de la primera cuarteta a que éstas sirven en los otros romances de 
glosa, es mas bien que una pintura de los trabajos que padece el que sale a rodar tierras, una relacion de la ceremonia en que el hijo pide la bendicion a su madre i de los consejos que ésta le da ántes de la partida. Júzguese de esta composición por su primer décima:

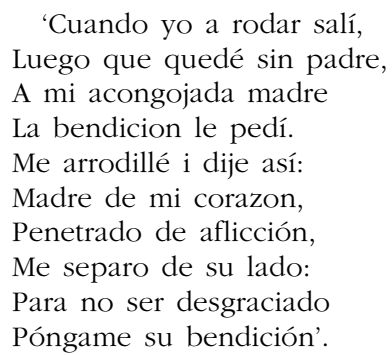

;A las calduitas, mi alma! como lo indica su título, es una composicion que tiene por objeto elogiar la especialísima clase de empanadas, conocidas con el nombre de caldudas o pequenes, artículo esclusivamente santiaguino. Guajardo habla de las caldudas i de las fábricas en que se elaboran con la minuciosidad de un conocedor i el entusiasmo de un aficionado. Si hubiese maliciosos que pusiesen en duda el desinteres de sus recomendaciones, juzgando talvez al poeta cohechado por los calduderos, éste los invita a que prueben por sí mismos, para que así salgan de su error:

'Madrugue por la mañana

Quien quiera salir de duda

I tómese una calduda

A ver si quita la gana.

Una fábrica arribana

Las trabaja con peras;

Mas por ciertas vinagreras

Paralizó su trabajo,

I a ésta la echaron abajo

Las fábricas pequeneras.
Me dicen que hai un mancebo

En el barrio de la Viña

Que sus pequenes aliña

Con pasa, aceituna i huevo.

Otro fabricante nuevo

Hai por la línea del tren;

Muchas fábricas se ven

En la misma capital

I todas en general

Están portándose bien'.

¿Habeis oido hablar de José Harnero? Probablemente no. Nosotros no oíamos hablar de él, desde aquella edad feliz en que todo se cree, i sobre todo en aquello que se nos presenta ataviado con los encantos de lo maravilloso. Lo vimos empero retratado en un romance de Guajardo i en el acto lo saludamos como a un antiguo conocido.

José Harnero es el judío errante de nuestros peones; un eterno rodador de tierras que viaja a pié, de ciudad en ciudad, de villa en villa i de aldea en aldea. No hai lugarejo que no conozca, ni bodegón en que no tenga compadres, ni suceso raro de que no haya sido espectador. José Harnero, cambiando incesantemente de residencia, obedece sin duda al destino; mas ipor qué, siendo conocido en todas partes, es conocido en todas bajo nombres diversos? ¿Es por ventura un malhechor que desea desorientar así a los ajentes de la policía? ¿O va cambiando de nombre por hacer mas singular i misteriosa su existencia de vagamundo? ¡Quién sabe! Lo único que noso- 
tros sabemos es que si José Harnero no viviese cambiando eternamente de residencia i de nombre dejaria de ser José Harnero.

El que nos retrata Guajardo, vaga por cincuenta lugares diferentes i toma en cada uno de ellos un distinto apellido. En una sola parte se llama con su nombre propio -José Harnero- i esta parte es en el Carril. Véanse la primera i última décima:

'En Maule soi Escobar,

En Talca soi Cheverría,

En Curicó soi García,

En Teno soi Sandovar.

En Chimbarongo Aguilar,

En San Fernando soi Vega,

En los Barriales Villega,

En Rehuelemo Negrete,

En Limahue Navarrete,

I en Pelequen soi Venega.
En Limache soi Pavés,

En San Pedro soi Cañete,

En Quillota soi Astete,

En Llai-llai soi Montanés.

En San Felipe Jerez,

En los Andes Escudero,

En Chacabuco Guerrero,

En Colina soi Asagra,

En la capital Villagra,

I en el Carril José Harnero'.

Terminaremos con los romances de costumbres, de Guajardo, diciendo algunas palabras sobre el titulado Los Tachadores, que es el único en que el autor (dando en ello un hermoso ejemplo de modestia i de buen gusto a sus colegas, no sabríamos decir si de oficio, de arte o sacerdocio) se toma así [sic] mismo por tema de sus coplas. Parece, en efecto, que éstas, dando a Guajardo alguna fama i algunas monedas, honos et proemium, le han sucitado tambien no pocos enemigos. Con el fin de contestar a sus tiros, el censurado poeta compuso Los Tachadores, esposicion rimada de los cargos que la malevolencia le dirije i de las alegaciones con que el acusado defiende lo que podríamos llamar la honorabilidad de su industria i la excelencia de la mision civilizadora a que ha consagrado su injenio. Oigámoslo:

Porque vendo papelitos

A un centavito o a dos, Me insultan jválgame Dios!

Los envidiosos malditos.

Si estoi refiriendo un verso

Se para el tonto de firme,

A tacharme, i a decirme

Que es falso lo que converso.

Los de corazon perverso

Son unos animalitos,

En dos patas paraditos,

De estraordinario tamaño;

Estos creen que al pueblo engaño

Porque vendo papelitos.

No es engaño ni locura,

Aun creo ser conveniente,

Que por mí bastante jente

Se aficione a la lectura.

Esta es una verdad pura

Tan fija como el reloj:

Solo los de alma feroz
Murmuran i se van riendo, Cuando un verso estoi vendiendo

A un centavito o a dos.

Tambien dicen e[s]tos tales

Cabezones i sin sesos:

— ¡Vé cómo tienen los lesos

Rodeado a Pedro Urdemales!

Los murmurones fatales

De hambre no sacan la voz,

Mas yo digo déjenlos

Pasar que son insensatos,

A mí hasta los mentecatos

Me insultan ¡válgame Dios!

Otros necios del infierno

Me suelen amenazar,

Que me van a denunciar

Como traidor al gobierno.

Estos no importan un cuerno,

No son mas que chinchositos,

Chuzos alborotaditos,

Que en las tabernas se agrupan, 
I en tachar no mas se ocupan Los envidiosos malditos.

Al fin, ya verán señores, Los que mas discretos fueren, Que estos versos se refieren A los simples tachadores.
Por cierto a los habladores

Su buena racion les toca;

Dejen esa idea loca,

No sean de mala fé,

$\mathrm{Ni}$ mas me obliguen a qué

Les ponga otro tapa-boca.

Si de estos romances que hemos llamado de costumbres pasamos a los picarescos, nos vemos ante todo en la imprescindible necesidad de eliminar por groseros e indecentes los titulados La fea, La pulga presera, El lazo de verijas, el que comienza

'Entre todas las mujeres

No hai mujer como mi Juana,

Ella sale a la oración

I vuelve por la mañana',

i algunos otros.

IV

Si Guajardo emplease principalmente los instintos poéticos con que Dios lo ha favorecido en escribir composiciones de ese jénero, si ellas no tuviesen la disculpa de la ignorancia i del deseo de obtener los aplausos de los necios, que forman la mayoría de todo público, i con mucha mas razon del público de poncho, los tachadores malditos, de quienes se queja el componedor de coplas i vendedor de papelitos en el romance que íntegro dejamos copiado, no habrian andado tan léjos de la verdad i de la justicia. Pero felizmente las tales composiciones son pocas, de manera que si el cura que espurgó la librería de don Quijote resucitase i se diese el trabajo de hacer otro tanto con las obras completas de Guajardo, no pasarían de ocho las que reputaria de merecedoras de la hoguera.

Faltaríamos a la verdad, sin embargo, si omitiésemos a propósito de estas composiciones una circunstancia importante. Las que vulgarmente se llaman coloradas son las mas leidas, mucho mas todavía que las mejores i mas leidas de otros géneros itriste síntoma que está revelando los groseros instintos de las últimas clases de nuestra sociedad i el grado de abyeccion en que se encuentran!

Es de notar tambien, para mantenernos en los límites de la mas estricta imparcialidad, que cuando Guajardo trata de hacer reir guardando a la decencia sus fueros, rarísimas veces lo consigue. Así despues de hecha la eliminación de los romances que no pueden citarse por la mala calidad de su sal, no encontramos ni uno solo bastante salado para merecer los honores de una transcripcion íntegra.

El que empieza

'Echale caldito Juana,

Que ya me voi mejorando;

El que se enferma tomando

Con el mismo licor sana', 
es una larga i desabrida glosa del refran, tan acreditado i practicado entre los adoradores del dios de las vendimias - un clavo saca otro clavo.

El titulado Tiro a los bolseros de puchos es, intencionalmente, al ménos, una sátira contra la numerosa ralea de los que no saben abrir la boca, ni para hablar, ni para comer, ni para echar humo si quiera, sino a costillas del prójimo. ¡Lástima que la ejecucion no hubiese correspondido al tema!

Mui superior nos parece el consagrado a referir i ponderar los trabajos a que vive condenado el sexo feo por complacer al bello, que según Guajardo no posee en dosis mui considerable la virtud del agradecimiento. Laméntase él en efecto de que

\author{
'Trabaja el hombre i padece \\ Desdichas por tener plata \\ Para la mujer ingrata, \\ I ésta no se lo agradece'.
}

I prosigue en cinco décimas pintando la desdichada condicion del hombre, i comparándola, a fin de encarecerla por el contraste, con la rica variedad de dones que Dios prodiga sobre las aves, los animales i los peces. Léase la primera:
'Nace el ave iqué grandeza
Entre su delicia suma!
Le viste la piel de pluma
La misma naturaleza.
I así que a volar empieza
En sus cánticos parece
Que a Dios sus dones ofrece,
Con amor tierno i profundo;
I solamente en el mundo
Trabaja el hombre i padece'.

¿Es una ocurrencia nuestra o hai en esta décima algo como un eco apagado, como un recuerdo vago i casi desvanecido de aquellas tan sentidas como famosas de Calderon que empiezan

\author{
'Apurar cielos pretendo \\ Ya que me tratais así, \\ ¿Qué delito cometí \\ Contra vosotros naciendo?'
}

El lector juzgará.

La melancolía, que apunta apénas en las décimas anteriores, forma el fondo i la nota dominante de algunos otros romances de Guajardo. En la que tiene por título Eterna separación de los amigos con la muerte, llora la brevedad de la vida, lo instable de la fortuna i la amargura del último trance. El tema es abundante; pero no corresponde a él la ejecucion. En El cisne que solo canta la víspera de su muerte, el poeta se pregunta así mismo la causa de tan raro fenómeno.

'Ave que en toda tu vida

No has merecido alegrarte, 
¿Por qué vienes a entonarte

Al tiempo de la partida?

¡Cómo! ¿Cuál es tu alegría

Que de ella nada adelantas,

I si tus ecos levantas

Ya son para no existir?

¿Qué alcanzas a distinguir

¡Oh! cisne, que al morir cantas?'

I acentuando mas la intención de figurarnos en la peculiaridad que la tradición atribuye al cisne, el dulce presentimiento de la bienaventuranza que el alma del justo debe experimentar en la hora de su muerte, concluye

'Casi llego a presumir

Que, pues que tu fin se acerca,

Solo cantas, ave terca,

Como para revivir'.

Falta mucho, no hai duda, a la espresion; pero la idea es tan hermosa i delicada, como digna de los mas ricos atavíos de la poesía. ¿A qué jénero pertenece el romance bautizado con estrambótico título de Los espolones del diablo? A ninguno de los clasificados en los manuales de literatura, i con perdon de los dichos manuales, al que llamaremos nosotros jénero estravagante-disparatado: al mismo a que pertenecen aquellos conocidos versos tan populares en las fondas:

'De las aves que vuelan

Me gusta el chancho,

Porque las esperanzas

Nunca se pierden'.

I aquellos otros de pata en quincha:

¡Vamos remoliendo, mi alma,

Que el infierno se ha vuelto agua;

Los diablos se han vuelto pejes

I los condenados taguas!'

Sobre éstos i los de su especie los de Guajardo tienen una ventaja, sin embargo, i consiste en que hai en ellos envuelto un atrevido pensamiento, que el poeta se declara dispuesto a realizar mediante ciertas condiciones, condiciones que constan de la primera cuarteta.

$$
\begin{aligned}
& \text { 'Si Dios me presta el avío } \\
& \text { I San Pablo los pellones, } \\
& \text { Santiago las estriberas } \\
& \text { I el diablo los espolones'. }
\end{aligned}
$$

Aviado de semejante suerte, el bardo paladin se declara capaz de bajar al infierno i de hacer allí una de Dios es Cristo. Oigamos la relacion de las hipotéticas hazañas del héroe: 
Pongo toda mi esperanza En el Salvador divino, Para que el ángel malino No tenga conmigo alianza. Mi verdadera confianza Está en el Padre querido, Que a todos ha redimido; I desde que su hijo soi, A caballo al cielo voi, Si Dios me presta el avio.

Con órden del Padre Eterno, I armado de todas armas Echaré fuera las armas Que hubiesen en el infierno. Atropellaré al gobierno De infernales escuadrones, Acabaré las lejiones Si San Miguel el arcanje, Me facilita su alfanje I San Pablo los pellones.

Haré lo que hizo Judí Con Olofernes temible, Saldré del infierno horrible Triunfante como Daví; Temblarán de verme allí
Los calabozos i hogueras; Las mas espantosas fieras Serán como una figura, Si me da de su montura Santiago las estriberas.

Con la vara de José I las fuerzas de Sansón En el reino del Dragon Aun ni escombros dejaré. Las almas libertaré De sus eternas prisiones; I si esas dominaciones Me diesen batallas crudas Perderá la bolsa Judas I el diablo los espolones.

Al fin cuando dé la voz La trompeta de Jerónimo Adoraremos a Dómino, Que es el verdadero Dios. Temblará el infierno atroz I el mundo será acabado. Ese dia desgraciado Cielos i tierra verán, El milagro que a San Juan Dios le tiene reservado.

Hemos citado algunos romances de Guajardo que pecan contra la moral; imposible sería citar uno solo que pecase contra la fé católica. Hombre del pueblo, nuestro poeta, cae fácilmente en las groserías, indecencias e inmoralidades en que incurren los de su clase, sin mucho escrúpulo, pero se guardaría bien de abrigar la mas leve duda sobre los dogmas de la religión que profesa. ¡Germen inmortal de salud que aun los hombres mas ignorantes i rudos de nuestra república conservan en lo mas recóndito del alma, i que una mano caritativa puede tocar siempre con esperanzas de alcanzar rica cosecha de arrepentimiento i de progreso! Pueden los vientos de las pasiones arrebatar al árbol sus hojas, i las bestias de los groseros instintos despedazar sus ramas i quebrantar su tronco, mientras que allá en el fondo de su sér se mantenga viva la raiz de la fé, todo entierro debe reputarse prematuro por que la vuelta a la salud es posible.

Guajardo se muestra creyente sincero en sus poesías religiosas, i como todo creyente, no se contenta con creer, sino que experimenta el deseo de propagar las creencias que abriga por todos los medios que están a sus alcances. Sus poesías religiosas son de dos clases: unas destinadas a encomiar los misterios, sacramentos i ceremonias del catolicismo; otras a estorbar i contradecir la propaganda del protestantismo i la incredulidad. 
Fórmense los lectores una idea de los romances religiosos de Guajardo por el siguiente, que, como lo indica su título (El bijo pródigo) no es mas que una tosca relacion hecha de aquella tiernísima parábola del Evanjelio:

Yo soi el pródigo hambriento Que vengo desengañado, A buscar necesitado

De vuestra mesa el sustento.

Padre compasivo, vé A tu hijo desventurado; Yo soi aquel desgraciado Que mi herencia mal-logré; Últimamente llegué Al mayor abatimiento, Tan triste acontecimiento, Por necesidad me obliga A que con lágrimas diga: Yo soi el pródigo hambriento.

No niego, padre querido, Que para ti fui traidor, I conociendo mi error Vengo mui arrepentido, Lloroso i enternecido A tí me postro humillado; En lágrimas anegado Para que me perdoneis: Tu hijo soi, no me neguéis Que vengo desengañado.

Padre de mi corazon, En tanta flaqueza vengo Que ni alientos casi tengo
Para pedirte perdon;

No mires mi indignación

Ni lo mal que os he pagado; Mira el infeliz estado, La miseria i decadencia Con que llego a tu presencia A buscar necesitado.

Padre misericordioso, Recíbeme con agrado I trátame como a un criado, Que me llamaré dichoso. Lo abrazó lleno de gozo El padre, i en el momento Lo colocó en su aposento, I le hizo esta referencia: 'Tú tendrás con preferencia De nuestra mesa el sustento'.

Al fin con gran regocijo Mandó el padre que se hiciera Una boda i se sirviera Lo mas esquisito a su hijo; Allí mismo le bendijo I le redobló su dona: I si esto la fé lo abona, Es prueba mui evidente Que a todo el que se arrepiente Dios, sin duda, lo perdona.

Entre los de controversia, descuellan los que tienen por objeto apartar al pueblo del protestantismo, poniéndolo en guardia contra los ajentes de la sociedad bíblica. Los argumentos, como fácilmente se comprenderá, no son mui decisivos en contra de la reforma; pero no por eso debe creerse que Guajardo ha predicado en desierto. Desde el nombre de enganchadores que da el romancero a los propagandistas protestantes, hasta la descripción que hace de las iglesias protestantes,

Donde no tienen altares

La Vírjen ni ningun santo,

todo está perfectamente calculado para producir el efecto que el autor se propone.

Por lo demas, en las décimas de que nos ocupamos se encuentra consignado el escaso fruto que los propagandistas recojen. Según Guajardo, los renegados son pocos i no descuellan por la lucidez de su inteligencia. Véase la primera décima de la composición que tiene por título El Enganche: 
'Andan los enganchadores

Por aldeas i ciudades

Comprando almas i amistades

A los corrompidos peores.

El jefe de esos factores

Es mas hábil que el Maligno

De ningun mérito digno

Por ser obispo casado:

Solo tontos ha enganchado

Desde que a Santiago vino'.

Persiguiendo siempre el mismo objeto i queriendo apartar a su público mas i mas de los lazos tendidos por la propaganda protestante i su ignorancia, Guajardo estudia los oríjenes de la reforma i da al pueblo una leccion histórica sobre tan interesante acontecimiento de la siguiente manera:

Leyendo en un catecismo

Que de Europa se mandó

Ni que dudar me quedó

Lo que es el protestantismo.

Desde el año mil quinientos

Diezisiete en Alemania

Protestaron, i en Jermania

Fué la reforma en aumentos.

Lutero en esos momentos

Renegó el catolicismo;

Zuinglio en Suiza hizo lo mismo,

Tambien dió contra la fé.

Estas verdades hallé

Leyendo en un catecismo.

En la Francia fué Calvino

Quien a la Iglesia dió guerra,

Lo propio hizo en Inglaterra

Enrique VIII; pues vino

A ser el mas libertino

Que en la cristiandad se halló.

Cada uno de estos negó

De Dios el poder eterno

Dice el místico cuaderno,

Que de Europa se mandó.

Luego los reformadores

Levantan el estandarte

De rebelion, que reparte
Odio, cólera i errores,

Contra el Papa i sus doctores

El escarnio no cesó;

Su atrevimiento llegó

$\mathrm{Al}$ mas insolente punto,

Hablando sobre este asunto

Ni que dudar me quedó.

De Calvino es efectivo

Aquel milagro tan cierto

Por resucitar un muerto

Le quitó la vida a un vivo.

Hé aquí lo positivo

De los sabios del abismo.

¡Oh! anónimo fanatismo

Quien te lleva no te entiende!

Ninguno de ellos comprende

Lo que es el protestantismo.

Católicos no os dejeis

Engañar de esos sectarios

Racionalistas, templarios,

Farsantes como sabeis:

En Santiago lo vereis

Repartiendo cuadernitos

Biblias i falsos libritos

Que ni mirarlos podemos.

En el concilio veremos

Donde van esos malditos.

Por disparatada que la anterior lección pueda parecer, ella es inmensamente superior a cuantas nuestro romancero se ha atrevido a dar sobre otros ramos del saber 
humano. Porque es de advertir que nuestros poetas de poncho, imitando, justo es reconocerlo, el ejemplo que reciben de los de capa o de chaquet, disertan de omne re scibile, con admirable aplomo. La literatura, la jeografía, la historia natural, la astronomía, son otros tantos temas que el romancero esplota, procurando comunicar generosamente a los lectores la luz de su ilustracion propia.

Por desgracia, esa luz es tan escasa como de mala lei, i las lecciones rimadas de que hablamos dejarán por todo provecho a los que las reciban un cierto número de palabras cuyo significado les será imposible comprender. ¿Qué sabrá de astronomía, por ejemplo, un individuo cuando sepa que

El que al Sol va mas cercano
Es el planeta Mercurio,
Vénus sigue su preludio
Con recurso soberano.
Circulan en cierto plano
Dando de su luz aumento,
Jiran en un modo lento
Cada uno segun su orbita
A la distancia que dicta
La tierra del firmamento?

¿I no es esa décima una prueba irrefutable de que el profesor que hace la explicación quiere explicar algo de que el mismo no tiene ni siquiera la mas somera idea? ¿I cual se tendrá formada de las cinco partes del mundo quien las define i caracteriza en esta forma?

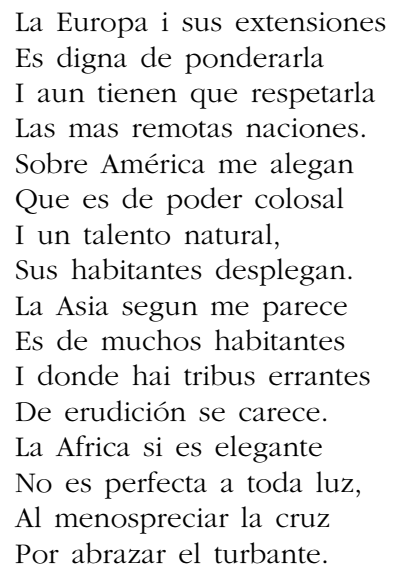

En suma, las poesías didácticas de Guajardo revelan en él la mas completa carencia de estudios hechos con algun método i seriedad. Se conoce a tiro de ballesta que solo a impulsos de la necesidad de componer (que acaso en el pobre mas de una vez se ha confundido con la necesidad de comer) ha ojeado uno que otro librejo i leido de vez en cuando algun artículo de diario. Así ha logrado conservar en la memoria palabras propias para producir efecto en un público completamente rudo e ideas confusas sobre ciencias, artes e historia. 
Hai, empero, entre todas las historias una que Guajardo conoce en sus menores detalles i que cuenta con harta mayor exactitud que la de la reforma relijiosa del siglo XVI. Esta historia es la contemporánea de Santiago. Como los antiguos romanceros, el que es objeto de estos apuntes, va consignando en su crónica rimada los sucesos, ora trájicos, ora venturosos, ya de carácter público, ya de carácter privado, que mas profunda impresión han causado al público. Aquí el cronista no elije sus temas sino que los soporta. Las circunstancias se los imponen, i él no hace mas que obedecer a la popular exigencia, constituyéndose en eco de la preocupación predominante del dia.

Para dar una idea de los sucesos cantados por Guajardo, i ya que no nos será posible copiar las composiciones de este jénero que merecerían ser copiadas, nos bastará indicar los temas de algunas de ellas. Las mas notables tienen por título: $E l$ anuncio aterrador del astrónomo Falb, El río Mapocho, Muerte de Lopez en el Paraguai, Sentencia de muerte i ejecución de Pedro Madrid, Profecía de las tres plagas anunciadas por el profeta de Australia, Los ajusticiados en el Campo de Marte, Gran temporal en Valparaíso, Orelie Antonio rei de la Araucanía i Patagonia, Incendio del Club de la Union, Gratitud a la Empresa de coches americanos, El rico descubrimiento de minas en Caracoles, Incendio del Piguchen de los Canacas, Nueva rebelion de los indios salvajes, La guerra entre Francia i Prusia i El mui famoso Ciriaco Contreras.

De entre los indicados romances trascribiremos como muestras el relativo al descubrimiento de Caracoles [en 1870], i el que narra la ejecución capital del famoso reo Pedro Madrid. Probablemente Guajardo se impuso del primero de estos sucesos leyendo los diarios (que aunque no es suscritor de ninguno, suele de vez en cuando comprar números sueltos) que por lo que toca al segundo no hai duda de que lo describe como testigo presencial. Véanse en el órden indicado el uno i el otro:

\section{EL RICO DESCUBRIMIENTO DE MINAS EN CARACOLES}

Es Caracoles hoi día

Un California en riqueza,

Se descubrió la grandeza

Que en aquella sierra había.

El primer descubridor

De aquel mineral, ha sido

Un chileno que ha podido

Internarse al interior.

I van con este señor

Otros tres en compañía,

Sin mas datos ni otro guia

Que su intelijente idea:

Soledad que lisonjea

Es Caracoles hoi dia.

La Suerte fué la primera

Mina que uno descubrió;
Este nombre se le dió

I es la que ménos prospera.

La San José se pondera;

En fé que tanto progresa, Mucha jente se regresa

A aquel vasto territorio

Que será, como es notorio,

Un California en riqueza.

Otras mas han descubierto

Como la Descubridora,

I se considera ahora

Mejor La flor del desierto.

Fuera de las que no advierto

Como se dice o se espresa,

Vamos allá que interesa

Caminar con todo apuro.

Ya ven que en ese estramuro 
Se descubrió la grandeza.

De Chañarcillo, mineros, A Caracoles se van, Entusiasmados están Apires i barreteros. I toda clase de obreros Cruzan por la travesía, Donde ménos se creia, Por el chileno que imploro, Fué descubierto el tesoro Que en aquella sierra habia.
Al fin, quien quiera marchar, Para que el desierto pase, Víveres de toda clase I agua es preciso llevar. Chile mandó inspeccionar La línea de aquel terreno; Que reconozcan es bueno Tal mineral me parece, Si a Bolivia pertenece $\mathrm{O}$ al territorio chileno.

SENTENCIA DE MUERTE I EJECUCIÓN DE PEDRO MADRID

Pedro Madrid sentenciado

A la pena capital

Como reo criminal,

Fué por las armas pasado.

No teniendo a qué apelar I viendo que iba a morir, Se conformó con decir: La debo i la he de pagar. Mucho se hizo por librar La vida a este desgraciado: Los ruegos del abogado No fueron de beneficio; Fué al afrentoso suplicio Pedro Madrid sentenciado.

Se le leyó la sentencia Con que hubo de conformarse, I para reconciliarse Examinó su conciencia.

Recibió con reverencia El ausilio espiritual:

Besó el estandarte real

De Jesus crucificado, Luego que fué condenado A la pena capital.

Cuando fué puesto en capilla Su próximo fin bendijo. A los pies de un Crucifijo
Con humildad se arrodilla; Como verdugo lo engrilla Un compañero desleal. Llegó el momento fatal, I fué al cadalso llevado Para ser ejecutado Como reo criminal.

No fué digno de perdon, Ni los empeños valieron: Los jueces el fallo dieron Con justicia por razon. Se cumplió la ejecucion Como se habia ordenado, Llegó el dia designado Para aquel trance funesto, I en el patíbulo puesto Fué por las armas pasado.

Al fin, esta alma dichosa Un Santo-Cristo llevaba, I solo en El se fijaba Sin pensar en otra cosa. Ya su espíritu reposa Entre aquellos cortesanos Que alegres i soberanos Visten de celeste velo. Lo dirijieron al cielo Los padres dominicanos.

Réstanos aun, para dar término a esta revista de los diversos jéneros que ha cultivado Guajardo, ocuparnos de los políticos i de los eróticos. No esperarán sin duda los lectores que vayamos a esponer aquí los principios sociales i políticos que for- 
man el credo de nuestro poeta. No los tiene, i no hai por qué estrañarlo. Sería mucho exijir que los tuviese un humilde trovador de poncho i de chambergo, cuando tantos escritores públicos, diputados i aun ministros del despacho, se dispensan de tenerlos.

Guajardo lo único que manifiesta en sus coplas políticas es simpatías i antipatías; i preciso es decirlo en su honor, completamente desinteresadas. Dejóse llevar en su tiempo por la corriente de opinion que echó por tierra al monttvarismo, sin que, al parecer, su aversion a ese sistema de gobierno tuviese por oríjen ningun desaire ni persecucion personal. Mas tarde, cuando la presidencia del señor Perez tocaba a su término i se abria la campaña electoral, cuyo desenlace fué el triunfo del señor Errázuriz [1871], Guajardo se apresuró a quemarle algunos granillos de su mejor incienso. En pocas palabras, nuestro hombre fué anti-nacional durante la administracion Montt; i porque era anti-nacional fué partidario del gobierno durante la administracion Perez. Pero como no fué un solo partido el que dirijió la política durante la última administración, siempre cabe preguntar: ¿Guajardo es liberal o conservador?

Tres son los romances políticos que de él tenemos a la vista, i en los tres, por diversas maneras, encontramos la contestación de la pregunta formulada. A fuer de creyente sincero, nuestro vate ataca al rojismo con la misma enerjía con que ataca al protestantismo: mas aun, casi podria decirse que para él rojismo i protestantismo son sinónimos. De ahí es que al atacar la candidatura Urmeneta, la atacaba principalmente por cuanto, en su concepto, su triunfo habia de importar el predominio de las disociadoras doctrinas de aquella escuela político-irrelijiosa. Por el contrario, ensalzó al señor Errázuriz i celebró su triunfo i elevación a la suprema magistratura de la república, porque el señor Errázuriz personificaba para él, como para tantos otros, el triunfo de la religión i de las doctrinas conservadoras.

La primera de las composiciones a que hemos aludido, que tiene por título Agonías del monttvarismo, concluye con esta significativa décima:

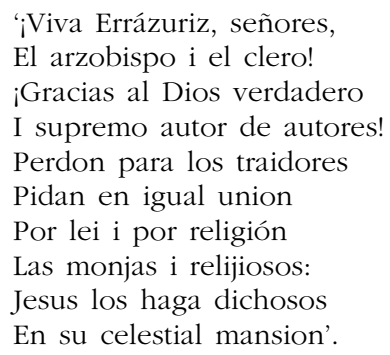

El otro que se titula Proclamacion del deseado presidente don Federico Errázuriz, alude tambien a la creencia, entónces comun, de que el candidato de abril contaba entre sus muchos títulos para dirijir los destinos de Chile el de simbolizar la causa de la relijion del país, por sus creencias personales i por los lazos que lo ligaban al partido católico.

\footnotetext{
'A la ceremonia o bando

Todo el pueblo concurrió,

I evidentes pruebas dió
} 
Que solo estaba deseando

Tuviese poder i mando

Aquel digno entre los dignos,

Que de tantos libertinos

Defendió la relijion;

I hoi lo llama la nación

Para rejir sus destinos'.

Finalmente del tercer romance que lleva por título ;Viva el señor don Federico Errázuriz! hacen a nuestro propósito las décimas tercera i cuarta, que dicen como sigue:

'Qué hiciéramos, Dios eterno,

Si gobernara el rojismo!

Chile sería un abismo

$\mathrm{O}$ un anticipado infierno.

Un tiránico gobierno

Siembra los campos de abrojos

Para cosechar despojos

Como sucede en la Francia.

Ya causan extravagancia

Las torpezas de los rojos.

\author{
Cuarenta i tantos periódicos \\ Por Urmeneta trabajan; \\ A don Federico ultrajan \\ Los diarios anticatólicos. \\ Con sus embustes diabólicos \\ No cesan de amenazar \\ Que al perder han de formar \\ Una gran revolucion: \\ Tan inicua pretensión \\ Caro les ha de costar'.
}

Por mucho que se conceda al entusiasmo del momento, por mucho que se cargue a la cuenta de la candorosa ignorancia del autor de las décimas copiadas, siempre será preciso reconocer que la opinión que emite sobre las ideas i programas del candidato de abril era entonces la predominante en el pueblo; i que esa creencia esplica, por una parte, el entusiasmo con que Guajardo animó a sus parciales durante la lucha i cantó su triunfo despues de obtenido éste; i por otra, el firme apoyo que el señor Errázuriz encontró en la clase obrera.

Hoi dia ¿cuál es el partido que cuenta con las simpatías de Guajardo? ¿Es un gobiernista o un opositor? Los dos años de gobierno que lleva el candidato de abril ¿le han traido la confirmacion o el desvanecimiento de sus esperanzas? -iQuién sabe! es decir, nada sabemos, porque no nos ha sido dable averiguar si en el año último nuestro poeta ha compuesto algun otro romance político. En todo caso, si lo ha compuesto, no ha llegado a nuestra noticia.

\section{[IX]}

El amor feliz i desgraciado es el tema de unos veinte romances de nuestro poeta. No hai que buscar en ellos ni la delicadeza de la espresion, ni la profundidad de los sentimientos, ni los primores del estilo. Guajardo está ya mui viejo para poesías amorosas. Sus esfuerzos por pintar lo que no siente lo llevan a las mas ridículas hipérboles i al empleo constante de comparaciones jerundianas i de metáforas disparatadas, que, preciso es decirlo, forman la trama de toda nuestra poesía popular. En décimas, corridos, romances, zamacuecas, resbalosas, etc., etc., jiran eternamente un amante que muere por su adorado tormento o su idolatrado dueño i alguna dama, que puede ser mas o ménos ingrata, pero que indudablemente será, preciosísima deidad, lucero 
resplandeciente, hermosa flor de las flores, luna dorada, águila real, encantadora princesa, blanca azucena, jardín florido, perla del oriente i un centenar de cosas semejantes. Las siguientes quintillas darán una idea del estilo de Guajardo en el jénero de que nos ocupamos:

Despierta, reina de amores;

Que me abras la puerta quiero;

Que te viene a visitar

Un amante pasajero.

Ya el sol i sus resplandores

Ilumina todo el mundo.

A deleitarte en las flores,

De ese sueño tan profundo

Despierta, reina de amores.

Con sus luces el lucero

Se dirije a saludarte;

Mas yo madrugué primero,
Para la noticia darte

Que me abras la puerta quiero.

No cesan de caminar

Las estrellas de una en una:

Presto las verás llegar

Alrededor de la luna

Que te viene a visitar.

Aviso tan lisonjero

Como éste no habrás tenido.

¡Qué gozo tan placentero,

A tu pieza te ha traido

Un amante pasajero!

En este mismo jénero amatorio encontramos otra composicion, en que el autor se olvida de poner a la cabeza de sus décimas la inevitable cuarteta cuyos versos son otros tantos piés forzados en que han de ir concluyendo las siguientes estrofas. El asunto de la composicion que vamos a trascribir es la Ausencia. El amante hace merito de las amarguras de la despedida, de su invariable constancia para no echar ni un momento en olvido a su perla del oriente, de sus inquietudes, de sus sueños, de sus desvelos; i despues de haber preparado así el terreno inclinando en su favor a la causante de tamaños estremos, concluye preguntándole con porfiada insistencia: ¿Dime si me has olvidado el tiempo que anduve ausente?

Hé aquí las cinco estrofas de que consta La Ausencia:

Penosa fué mi jornada

Luego que de aquí salí,

Porque no me despedí

De ti, preciosa adorada.

En mi ausencia dilatada

No te olvidé de mi mente,

I tú, perla de oriente,

Claro cielo iluminado,

Díme si me has olvidado

El tiempo que anduve ausente.

A cada instante o momento

Parece que te veia,

De modo que no podia

Borrarte del pensamiento;

Te daba mi sentimiento

Como que estabas presente;

I tú, en caso tan urjente

Por mi viaje demorado,

Díme si me has olvidado
El tiempo que anduve ausente.

Penetrado de ternura,

Decia: ‘ai de mí! ¿qué haré?

¿Cuándo otra vez volveré

A ver mi amada hermosura?

Así en esta desventura

Lloraba continuamente:

I tú, cual flor macilente,

Rosa del mas lindo prado,

Díme si me has olvidado

El tiempo que anduve ausente.

Distante de vuestro cielo

No podia merecer

Gusto cabal ni placer,

Alegría ni consuelo;

Este pesar o desvelo

Era mi peor accidente:

I tú, luna reluciente, 
O precioso sol dorado,

Díme si me has olvidado

El tiempo que anduve ausente.

Al fin en tan tristes casos

Caminaba sin demora

Por que no veia la hora
De reposar en tus brazos.

Con ajigantados pasos

Entre el peligro inminente,

I tú, de un modo aparente,

Tan léjos de tu adorado,

Díme si me has olvidado

El tiempo que anduve ausente.

Hemos citado largamente i aun a riesgo de abusar de la paciencia de los lectores. Vamos a permitirnos, para concluir con el primero de nuestros poetas de poncho, citar todavía un romance erótico-alegórico, que en su jénero se asemeja algun tanto al primero que copiamos al empezar estos apuntes con el título de Celos de la lora al loro.

Por cansadas que las citas que vamos haciendo puedan parecer, hacerlas fué el principal objeto que nos propusimos al escribir el presente artículo. Tratándose de poetas cuyas obras corran impresas en libros i revistas, las citas no son esenciales: el que desee leerlas para apreciar el juicio del bibliógrafo, sabe donde ha de encontrar lo que necesita. Con las obras de los poetas de poncho no sucede eso; porque si es verdad que ellas se han dado a la estampa, es dificilísimo, por no decir de todo punto imposible, consultarlas. Tal es el motivo que hemos tenido para ir dando muestras de los diversos géneros en que Guajardo se ha ejercitado: tal es la consideracion que nos mueve a citar todavía una mas ántes de despedirnos de él, para escribir un párrafo sobre su colega y émulo Juan Morales:

\section{LA PALOMA INGRATA}

En el centro de mi pecho, Una palomita crié;

Luego que se vió con alas

Suspendió el vuelo i se fué.

A esta palomita bella

La visitaba un palomo, I un dia, sin saber como, Voló i se me fué con ella; Como no dejó ni huella En llanto quedé deshecho: Lloro con justo derecho De ver cómo me pagó, Despues que se alimentó En el centro de mi pecho.

Al otro dia temprano Madrugué i salí a buscarla; No fué posible encontrarla $\mathrm{Ni}$ en el mas tupido llano: Corrí los montes en vano, Ninguna noticia hallé. Volví contemplando que Mas no habia de salir.
Para tener que sentir Una paloma crié.

Al hallarse desplumada, Era con su dueño amante, Mui humilde, mui constante I digna de ser amada: Volvió a su pluma dorada I adornó de ricas galas; Tomó precauciones malas Sin pensar en el engaño. Abandonó su rebaño Luego que se vió con alas.

Al fin de tanto cuidado Que para criarla tuve, Desapareció cual nube El dia ménos pensado; Penoso i desconsolado Desde aquella hora quedé, Ultimamente no sé A dónde pára o existe; Para dejarme mas triste Suspendió el vuelo i se fué. 
Señores, no hagan empeño A criar tales palomitas. En estando grandecitas Ya se van con otro dueño. Yo no pensaba ni en sueño
Que mi palomita hermosa, Tras de ser tan cuidadosa, En un descuido voló Para siempre i me dejó Con mi alma triste i penosa.

Vamos ahora a Juan Morales, quien no nos ofrecerá asunto mas que para unas cuantas pájinas. En efecto hai entre Guajardo i Morales una distancia enorme; i aun cuando no falten datos para creer que este último miraria (no podemos decir mira por una razon en que luego se verá) por sobre el hombro al primero, es lo cierto que toda comparacion sería injusta si es que fuese posible.

Morales tendrá diez o quince años menos que Guajardo. La única vez que lo hemos visto ha sido en la oficina de El Independiente, a donde habia ido a tratar la impresion de algunas de sus coplas. Su moreno semblante parece velado con esa sombra de vaga melancolía que es el distintivo de los ciegos; i en sus labios anda asomada siempre una triste sonrisa. Guíalo de ordinario un mozo que le presta, mediante un salario convenido, los servicios de lazarillo, de escribiente i de vendedor de sus composiciones poéticas. Así es que cuando se trata de componer Morales dicta i el secretario escribe, i cuando se trata de correjir las pruebas, ése lee i aquel oye con la mas profunda atención para dar a sus coplas la última mano.

Recordando aquel ejemplo de la Gramática latina que dice mas o menos Nunquam poeta nec oratos fuit qui ullum majorem quam se arbitraretur, i deseosos de comprobar su exactitud en lo que podríamos llamar dos poetas en bruto, movimos al ciego la conversación sobre su compañero i émulo Bernardino Guajardo. Le hicimos saber que habíamos reunido sus poesías con el propósito de escribir acerca de ellas un artículo, i agregamos que con la mas viva satisfaccion asociaríamos en ese artículo su nombre al de aquél.

Morales dió inmediatamente órden a su lazarillo de poner en nuestras manos las coplas que llevaba consigo, i nos prometió enviar a la mayor brevedad las demas. Despues guardó silencio. No duró este mas de un instante, sin embargo, porque tomando la palabra su secretario, dijo con notable satisfaccion lo que un sentimiento de modestia impedia revelar al interpelado.

'Guajardo, nos aseguró aquel entre falte, lazarillo i escribiente, es un poeta vulgar, un payador que tiene mal oido, i que desconoce las reglas del arte. Fuera de su inmoralidad, es chavacano, ignora la mitología i no tiene ni noticia siquiera de los grandes maestros. En sus romances religiosos llega con frecuencia a escribir herejías, porque es un hombre que, satisfecho con leer los diarios, que compra numerito por numerito, no se da el trabajo de estudiar buenos libros ni de asistir a las funciones relijiosas para instruirse'.

'Morales, agregó, no ha compuesto tanto; pero sus romances tienen armonía i están fraguados segun las reglas del arte. Tiene un oido tan fino, que con solo escuchar la lectura de un verso sabe decir en el momento, i sin contar las sílabas, si le falta o le sobra alguna. Está siempre al corriente de los nombres de los oradores sa- 
grados que predican en todas las iglesias, i oye con muchísimo interes sus sermones. Tiene ademas una prodijiosa memoria para retener lo que oye leer o decir; i a medida que va dictando sus versos los va guardando en la imajinación; pues concluir el último i comenzar otra vez por el primero para ir recitándolos todos sin turbarse es todo uno. Ahora en cuanto a libros, Morales tiene en su cuarto hasta una docena. Opúsculos de propaganda religiosa, una gramática, el Mensajero del pueblo, i sobre todo, el Año cristiano (Flos sanctorum) i el Catecismo explicado. En resumen, Guajardo es un payador, que compone versos sin ton ni son, mientras que Morales compone los suyos ajustándose a las reglas de la poesía'.

Mas o ménos, fué eso lo que nos contestó por su maestro el secretario de Juan Morales, con un tono que, a pesar de su vehemencia, nos dejó perplejos, no sabiendo si atribuir aquel calor a admiracion sincera o a interesada cortesanía. Sea de ello lo que fuere, el hecho es que el maestro escuchó aquellas invectivas contra su rival i aquellos elogios a quema ropa en el mas profundo silencio i la impasibilidad mas completa; silencio e impasibilidad que, a no estar nosotros equivocados, indicaban la aprobación completa que el ciego i reservado trovador se dignaba acordar a las palabras de su despercudido lazarillo.

¿Qué hai de verdad, empero, en el fondo de aquel juicio? Mui poco, desgraciadamente; tan poco como suele encontrarse en los juicios que el amor propio forma $i$ que los cortesanos metidos a críticos repiten i exajeran. Morales será tan instruido como se quiera, puede tener una memoria tan maravillosa como la que tuvo Artajérjes Memnon; pero con todo eso es mucho ménos poeta que Guajardo: i es ménos poeta porque es mas pretencioso, i por lo mismo que hace esfuerzos continuos por salir del mundo en que vive, que es el que conoce i que apesar de sus miserias es para los hombres de su condicion la única fuente de fresca i de orijinal poesía.

¿Cómo comparar, por ejemplo, no diremos ya Los celos de la lora al loro, pero la Ejecucion de Pedro Madrid, ;A las calduditas, mi alma! u otros romances semejantes de Guajardo, con el siguiente de Morales que tiene por título: Breve compendio de la vida de San Agustin?

San Agustin alcanzó

Una feliz conversion:

Confundiendo la herejía

Se hizo un célebre doctor.

Fué San Agustin, se cree, Jentil ántes de ser santo, El cual vivió tiempo tanto Mui aparte de la fé.

Miéntras que pagano fué

A estremo se pervirtió,

Hasta que Dios le sacó

Del estado del error:

La contrición i dolor

San Agustin alcanzó.

Se fué a un huerto apresurado

I allí lloró amargamente,

Sus ojos fueron torrente
Del puro llanto anegado, Hasta que vió fulminado De sus culpas el perdon; Inspiró en su corazon

Dios los dones de la gracia, I logró con eficacia Una feliz conversion.

Ejerció con vivo celo Las prácticas de piedad, Pues la fé i la caridad Eran su único consuelo. Tuvo los dones del cielo De ciencia i sabiduría; Muchas almas convertía En las partes donde andaba; Solo se preocupaba Confundiendo la herejía. 
A muchos pueblos perdidos

Los sacó de sus estrávios,

Discutia con los sabios

I filósofos impíos,

Dejándolos confundidos,

Llenos de asombro i terror;

Esparció con esplendor

De la Iglesia el fruto ameno,

Por su entendimiento pleno

Se hizo un célebre doctor.
Al fin, progresó bastante

Este varón apostólico;

Nuestro símbolo católico

En defender fué constante,

Saliendo en todo triunfante

Con su inspirada moral.

En Hipona, ciudad tal,

El recibió el obispado,

I hecho obispo, fué elevado

A la silla episcopal.

No hai ahí ni gracia, ni verdad, ni sentimiento; en una palabra, ni una chispa de poesía. El instinto de nuestro pueblo no se ha engañado en sus preferencias. Sin dejarse llevar de la novedad ha seguido pidiendo coplas i mas coplas a su viejo romancero, cuya estrella léjos de apagarse con la aparicion de un rival, parece haber cobrado nuevo brillo. La cocinera i el peon, i la verdulera i el cargador, no han rehusado sus centavos al poeta ciego; pero continúan buscando con mas entusiasmo que nunca las producciones del poeta tuerto.

Esa preferencia es como un dardo que Morales lleva clavado en el corazon. Probablemente acusa en su interior a su público de ignorante i grosero; i sin duda ninguna su rival le parece mui inferior a la fama de que goza i a las ganancias que realiza. El romance siguiente es una invectiva en toda forma. Se titula Juicio crítico contra los poetas, i en buena verdad debería titularse Una tunda a Guajardo:

Requiere la poesía

Arreglo gramatical,

Un don sobrenatural,

Un buen gusto $i$ armonía.

Contra varios rimadores Hablo, segun mi opinión, Que por falta de instrucción Han sido hechos acreedores

De los mas graves errores, Como se ve en nuestros dias.

Es preciso que por guia

Se ponga el divino Homero,

Porque perfeccion i esmero

Requiere la poesía.

El que nada ha progresado

Para el arte no es propicio,

I por un prudente juicio,

Este será reprochado.

¡Ai! del que vive abismado

En una ignorancia igual!

Una voz fundamental

Dice en la regla prescrita:

Toda estrofa necesita

Arreglo gramatical.
Hai poetas que fujitivos

Viven de estas persuasiones,

En cuyas composiciones

Dividen los sustantivos, Muchos de los adjetivos. Este error llega a ser tal, Que mancha un cuadro moral: Luego de aquí se colije Que la poesía exije

Un don sobrenatural.

Este don ha consistido No solo en el bien rimar, Sino tambien en pintar Los cuadros como es debido: Cada cual debe ir nutrido Con las voces de hidalguía; Siempre en la Mitología Se apoyará cualquier tema, Para que tenga el poema Un buen gusto i armonía.

Al fin, hago esta censura, Sobre el que ignorante vive, Por la regla que prescribe La bella literatura, Grata, dulce, suave i pura; 
Pero añadiendo en tal caso Que a Virgilio i Gracilazo I a otros mas ha de estudiar
Aquel que quiera llegar

A la cumbre del parnaso.

Por si acaso las líneas que acabamos de escribir llegasen a ser leidas por los poetas que nos las han sujerido con sus singulares producciones, vamos a terminar dándoles dos consejos que pueden serles útiles: el uno referente a la forma i al fondo el otro.

Déjense de décimas con pié forzado, porque miéntras insistan en la manía de trazar ese círculo para jirar dentro de él como un jinete de circo, no les será dable alcanzar aquella soltura i espontánea i graciosa naturalidad, sin las cuales puede haber dificultades vencidas, pro no habrá jamas ni bellezas alcanzadas, ni corazones dulcemente impresionados.

La forma que conviene a nuestros poetas de poncho es el romance, es decir, la forma clásica de la poesía popular española. Es hora buena que se tenga El año cristiano en la silla mas inmediata a la cabecera de la cama, i que cada noche se lea, i se medite i haga el propósito de imitar la vida del Santo del dia; mas deséchese como una mala tentacion la idea de ir a buscar allí argumentos de poesía popular.

Esos argumentos (i éste es el consejo relativo al fondo que deseamos dar a nuestros dos poetas), se encuentran donde quiera que el pueblo se reuna, i trate de sus negocios, de sus sentimientos o de sus placeres: en la plaza de abastos, en los conventillos, en las canchas de bolas, en las fondas de la pampa, en los hospitales, en las procesiones, en las trillas, en los rodeos, en los mingacos, etc., etc.

Observad bien a vuestros hermanos, diremos para concluir a nuestros poetas de poncho, en todas las circunstancias de su vida: escuchad como hablan, mirad como se mueven, penetrad en su interior, i sorprendiendo las causas de sus pesares i de sus alegrías, haceos los intérpretes fieles de éstas i de aquellos, olvidándoos de la eterna cuarteta i de los malditos piés forzados, i leyendo ántes de poneros a escribir una pájina del Tesoro de romanceros españoles, coleccionados por don Eujenio de Ochoa.

Setiembre 5 de 1873

ZOROBABEL RODRÍGUEZ

Fecha de recepción: 14 de septiembre de 2012

Fecha de aceptación: 17 de junio de 2013 